\title{
The Impact of the COVID-19 Crisis on Growth-Oriented SMEs: Building Entrepreneurial Resilience
}

\author{
Jelle Schepers $^{1, * \mathbb{C}}$, Pieter Vandekerkhof ${ }^{1}(\mathbb{D})$ and Yannick Dillen ${ }^{2}$ \\ 1 Research Center for Entrepreneurship and Family Firms, Hasselt University, 3500 Hasselt, Belgium; \\ pieter.vandekerkhof@uhasselt.be \\ 2 Entrepreneurship Department, Vlerick Business School, 9000 Gent, Belgium; yannick.dillen@vlerick.com \\ * Correspondence: jelle.schepers@uhasselt.be
}

Citation: Schepers, J.; Vandekerkhof, P.; Dillen, Y. The Impact of the COVID-19 Crisis on Growth-Oriented SMEs: Building Entrepreneurial Resilience. Sustainability 2021, 13, 9296. https://doi.org/10.3390/ su13169296

Academic Editors: Gian Luca Casali and Mirko Perano

Received: 2 July 2021

Accepted: 17 August 2021

Published: 19 August 2021

Publisher's Note: MDPI stays neutral with regard to jurisdictional claims in published maps and institutional affiliations.

Copyright: (c) 2021 by the authors. Licensee MDPI, Basel, Switzerland. This article is an open access article distributed under the terms and conditions of the Creative Commons Attribution (CC BY) license (https:// creativecommons.org/licenses/by/ $4.0 /)$.

\begin{abstract}
This study explores how the COVID-19 pandemic has forced Flemish growth-oriented entrepreneurs to build entrepreneurial resilience. We rely on a research framework that consists of a "challenge-reaction-learning loop" to empirically investigate how entrepreneurial resilience is built in times of the COVID-19 crisis. To investigate this complex entrepreneurial learning process, we use data that have been collected during the first and second wave of the COVID-19 pandemic. By using several datapoints, we could identify (1) the specific challenges growth-oriented firms are facing as a result of the COVID-19 crisis; (2) how these entrepreneurs reacted to these challenges; and (3) what they learned during the first and second wave of the pandemic and how they perceive the future. By making this entrepreneurial learning process explicit and dividing it into an iterative "challenge-reaction-learning loop", this study is relevant for all entrepreneurs, as it contains several interesting lessons learned. We also contribute to academic literature as we provide future researchers a tangible framework to further elucidate how entrepreneurial resilience is built in times of crisis.
\end{abstract}

Keywords: entrepreneurship; COVID-19; crisis; growth-orientation; resilience

\section{Introduction}

The economic crises of the past 20 years have led to a proliferation of studies investigating the impact of a crisis on entrepreneurship. Research to date has mainly focused on previous economic crises like the dot-com crash, e.g., [1,2]; the 2008 financial crisis, e.g., [3-6]; and natural disasters, e.g., [7,8] to investigate the impact of an economic crisis on entrepreneurs and their businesses. Although these studies have highly increased our general understanding of entrepreneurial best practices during and after an economic crisis, the ongoing COVID-19 crisis we are currently facing is of an entirely different order and its impact on entrepreneurship remains to be studied. Indeed, entrepreneurs have to face a new reality where billions of people around the world are affected by a huge sanitary and health crisis. Although entrepreneurs are generally known for their resilience, e.g., $[9,10]$, the COVID-19 crisis is confronting them with very specific challenges due to an unprecedented downturn in the global economy. Over-reliance on the lessons learned from past crises might result in "fighting new battles with old weapons" [11]. As academic research on this topic is still scarce, both scholars and practitioners are lacking evidence-based information in order to recognize and deal with the specific entrepreneurial challenges imposed by the COVID-19 pandemic.

Recent studies have made some first attempts to analyze how COVID-19 induces specific challenges for small business owners, e.g., [12-15]. Although these studies provide first estimates of the early-stage effects of COVID-19 on entrepreneurial challenges, these studies have exclusively focused on a specific segment, namely the small business landscape. This focus on the small business landscape is also noticeable in most government interventions which especially aim to support small business owners [11]. While these small business owners are numerous and therefore extremely important for our economy, 
researchers agree that only a select subset of companies with high growth potential significantly contributes to economic growth and added value, e.g., [16-18]. Furthermore, only a few firms with high growth potential generate a disproportionately large share of all new net jobs compared with non-high-growth firms, e.g., $[19,20]$. While the focus of existing COVID-19 studies has mainly been on small businesses, these companies-in general-are not the source of our economic vitality and job creation [20]. Especially in times of an economic crisis, our welfare is highly dependent on a select set of highly innovative and growth-oriented firms. Given the economic importance of these growth-oriented firms, we propose that it is especially relevant to investigate how the current COVID-19 pandemic is affecting these companies.

Over the last few months, a vast amount of academic research addressing the changing entrepreneurial landscape as a result of the COVID-19 crisis has tried to make sense of this crisis situation. Unfortunately, due to the urgency and topicality of this new phenomenon, most of these academic perspectives took the form of conceptual papers, editorials, and commentaries, since primary data from entrepreneurs during the emerging COVID-19 crisis are very scarce [21]. Although these studies are certainly helpful contributions, they naturally lack the necessary rigor and evidence to sufficiently assess the impact of the COVID-19 crisis on entrepreneurial phenomena, like entrepreneurial resilience [21]. Therefore, this study aims to fill this gap by empirically investigating how growth-oriented firms have been impacted by the ongoing COVID-19 pandemic. By exclusively focusing on a select subset of growth-oriented firms, this exploratory study follows Kuckertz and Brändle's [21] recent call to take into account the specific 'context' of the firms under investigation prior to the crisis, as this context might influence the way in which entrepreneurial resilience is built. Therefore, the common context of the firms under investigation in this exploratory study is that all firms in our sample had an explicit growth-orientation prior to the crisis. This explicit growth-orientation is the ideal research context to investigate the development of entrepreneurial resilience since prior research has shown that the perceived challenges and respective actions during an external environmental crisis are highly influenced by an organization's strategic orientation. Unfortunately, attempts to understand organizational responses to external threats have drawn on bodies of research that led to conflicting conclusions, and more in-depth research is warranted, e.g., [22], to better understand how an organization's strategic orientation prior to a crisis affects their perceptions and actions during environmental threats.

Therefore, the aim of this explorative study is threefold. First, by collecting data during the first and the second wave of the COVID-19 pandemic, we aim to identify the specific challenges growth-oriented firms are facing as a result of the COVID-19 crisis. Second, given these specific challenges for growth-oriented firms, we also aim to present how entrepreneurs reacted to these challenges during the ongoing pandemic. Third, the final objective of this study is to investigate the lessons learned and how entrepreneurs of growth-oriented firms perceive the future. By answering these research questions this explorative study clarifies the process of building entrepreneurial resilience in growthoriented firms.

In what follows, we start with a literature review where we position this study in the academic literature on growth-oriented firms and entrepreneurial resilience. We end the literature review with an overview of our research framework. Next, we describe our sample by giving a situational background of the Flemish COVID-19 situation and describe how and when our data were collected. In section four, we provide a detailed overview of our results. We end this explorative study with a discussion and conclusion by linking our main results to existing debates in academic literature.

\section{Literature Review}

\subsection{The Importance of Growth-Oriented Firms during and after an Economic Crisis}

The reputation of growth-oriented firms in terms of economic development and job creation has been long recognized in the growth literature, e.g., [16-18]. The empirical 
evidence from different European countries is compelling and shows that only a limited set of fast-growing companies creates a large number of jobs, e.g., [23-25]. European figures show that 3 to 6 percent of the fastest growing firms generate up to $70 \%$ of new jobs in established firms [26]. For this reason, growth-oriented firms have also received attention and support from a policy perspective by the European Commission, e.g., [26,27] and the OECD [28]. Especially after the 2008 financial crisis, high-growth firms were deemed as a cornerstone in strategic growth plans to permit countries to initiate a sustainable growth path and to create new jobs. Surprisingly, our understanding of the specific challenges and ways in which these growth-oriented firms achieve their growth, especially in times of an economic crisis, is still scarce [29]. Yet, European figures show that during economic crises there are fewer growth-oriented firms that actually succeed in realizing their full growth potential [26]. Research has shown that entrepreneurial resilience is one of the key constructs determining entrepreneurial success during and after an economic downturn. Therefore, this study uses an entrepreneurial resilience perspective to study the challenges, reactions, and aspirations of growth-oriented entrepreneurs during the COVID-19 crisis.

\subsection{Building Entrepreneurial Resilience}

Resilience has been investigated in a variety of contexts [30], including psychology, e.g., [31]; sociology e.g., [32]; ecology e.g., [33]; gerontology, e.g., [34]; and education, e.g., [35]. Depending on the context of these studies, the concept of resilience has been defined in different ways and a plethora of related concepts such as resiliency, transformability, persistence, preparedness, or adaptability have been used [36-38]. In general, resilience is seen as both "an ability to go on with life, or to continue living a purposeful life, after hardship or adversity" [39] (p. 4) and "a dynamic process encompassing positive adaptation within the context of significant adversity" [37] (p. 543). People can build resilience through everyday developments resulting from unforeseen events in their life [40]. Therefore, resilience is best understood as a process [41] where individuals, firms, communities, or macro-level entities adjust to new contextual conditions. Indeed, most research shows that resilience is mainly the result of an interactive process between individuals and their environment rather than a fixed individual trait [41,42].

Following the increased scholarly attention in different research domains, the concept of resilience also found its way to the entrepreneurship domain. Resilience appears to be very important for entrepreneurs as they frequently have to face disruptive conditions, impacting their ability to integrate, build, and reconfigure resources [43-45]. Disruptive conditions can be either internal, such as a key employee leaving the firm, or external, in the form of an economic crisis or other threats the firm cannot control [43]. In sum, entrepreneurial resilience has been identified as a crucial element in the entrepreneurial process, e.g., $[10,46]$.

In their theoretical framework on entrepreneurial resilience, Manfield and Newey [43] suggest that entrepreneurial resilience is a process that needs to be developed and learned in relation to specific threats. For example, an internal threat resulting from a key employee leaving the firm requires different entrepreneurial resilience capabilities than an external threat resulting from an economic downturn. Manfield and Newey [43] suggest that the development of entrepreneurial resilience capabilities can be learned but depends on the type of threat the firm is dealing with. They state that entrepreneurial threats can vary, for example, in terms of severity, frequency, novelty, and complexity. Depending on the type of threat, the entrepreneurial resilience capabilities needed to respond to this threat must be different. Furthermore, the way in which a firm is impacted by a threat is also firm-specific. For example, presented with the exact same threat (e.g., an economic crisis), growth-oriented firms may face a different challenge and consequently require different entrepreneurial resilience capabilities than a large multinational company.

Entrepreneurial resilience is thus context-dependent and includes a set of cognitions, behaviors, skills, and processes that emerge from the enactment of a capability portfolio. An organization's capability portfolio ideally comprises both operating capabilities and 
dynamic capabilities $[43,47]$ that should allow an entrepreneurial firm to be resilient and respond to threats. Operating capabilities are usually routine-based and support a firm in executing its key operating activities $[48,49]$. Dynamic capabilities, on the other hand, are defined as the firm's ability to reconfigure operating capabilities and thus allow the firm to adapt and evolve [44,47]. Firms need both operating and dynamic capabilities in order to survive. Dynamic capabilities are necessary to adapt and change while operating capabilities are needed for stability [44,50]. Recent definitions in academic literature distinguish between operational ("how you earn your living") capabilities and dynamic ("how you change your operational routines") capabilities [49,51,52]. Operating capabilities require a certain amount of routinization and enable the firm to execute its main operating activities such as making and selling products or delivering services $[47,49,52]$. In the face of an exogenous shock, like the COVID-19 crisis, such routinization can potentially become the source of inertia, market irrelevance, and eventually failure [44,47]. Dynamic capabilities can oppose this effect and are described as the firm's ability to reconfigure operating capabilities and consequently allow the organization to adapt and evolve [47,48,50]. For example, strategic decision making can be seen as a dynamic capability in which entrepreneurs pool their various business, functional, and personal expertise to make the choices that shape the major strategic moves of the firm, e.g., [53,54]. Thus, especially in times of an economic crisis, entrepreneurial resilience is highly dependent on the dynamic capabilities of a firm as firms need to adapt and evolve. Namely, a firm's response to an economic crisis can range from no reintegration (leading to economic failure), to partial reintegration (lower performance than before the crisis), to full reintegration (same performance as before the crisis), or even resilient reintegration (better performance than before the crisis) [43]. The idea of resilient reintegration is similar to the idea of post-traumatic growth in psychology, where positive change occurs as a result of the struggle with highly challenging life crises [39]. Unfortunately, little is known in entrepreneurship literature on how firms can build entrepreneurial resilience.

Therefore, this explorative study aims to unravel the process of building entrepreneurial resilience in growth-oriented firms by looking at the capabilities developed as a response to the COVID-19 crisis. We do this by collecting data during the first and second wave of the ongoing COVID-19 pandemic and investigate the following research questions: (1) what are the specific challenges growth-oriented firms are facing as a result of the COVID-19 crisis; (2) how did entrepreneurs of growth-oriented firms react to these challenges; and (3) what are the lessons learned and how do entrepreneurs of growth-oriented firms perceive the future. This resulted in the following research framework (Figure 1). 


\section{CHALLENGES}

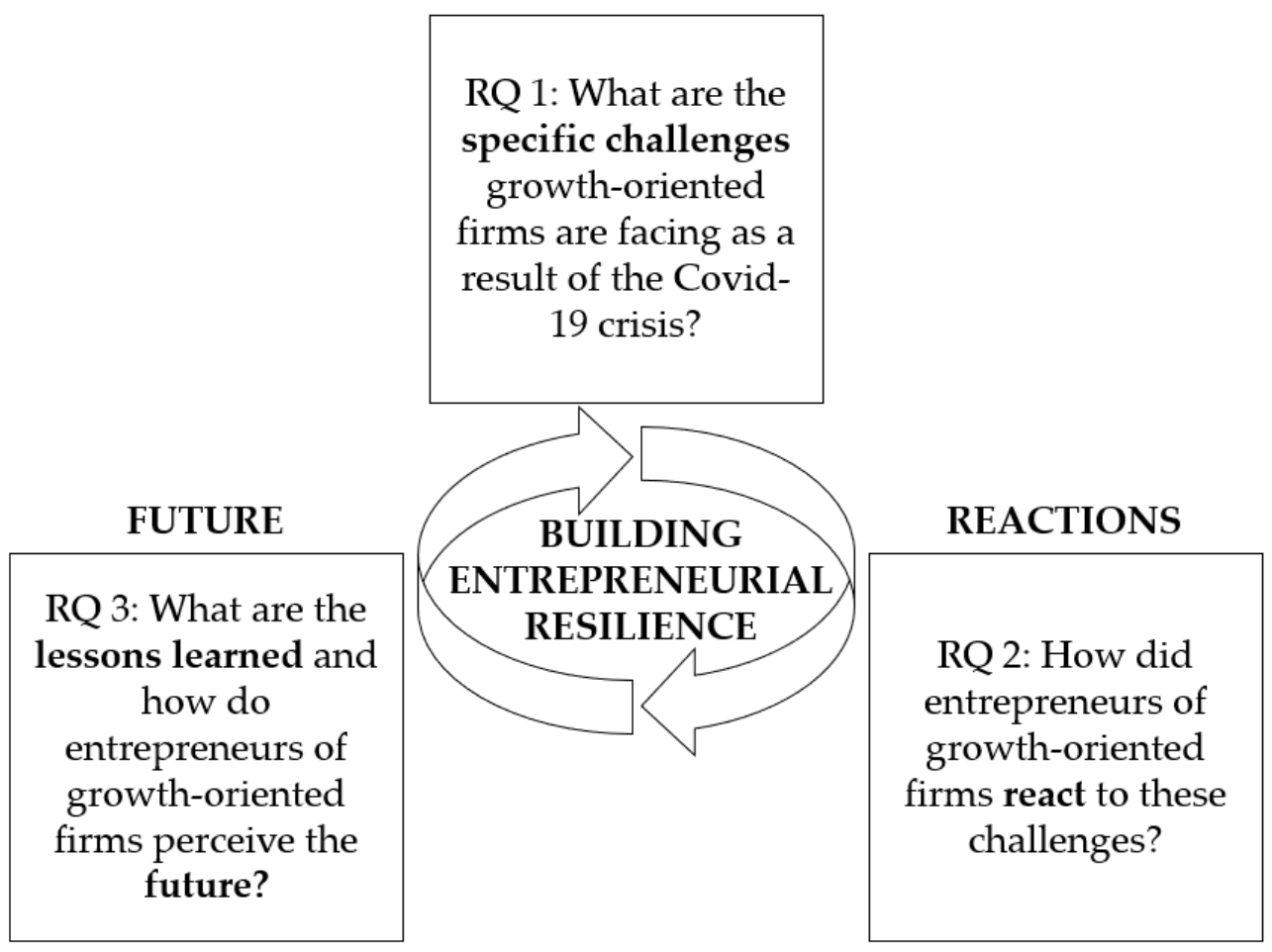

Figure 1. Research Framework.

\section{Sample: Background and Description}

\subsection{Situational Background}

\subsubsection{Public Health Situation}

Even though the emergence of COVID-19 has a worldwide impact, the evolution of the waves, based on the number of daily infections as well as daily hospitalizations, differed from one country to another. Those two parameters were the main drivers for political, social, and economic measures taken to prevent the virus from expanding and avoid large economic downturns.

In order to explain the relevance of our data period, we link the timing of our data collection with the evolution of the Flemish epidemiological situation over time. More specifically, we report the evolution of the two main parameters, the number of daily infections (see Figure 2) as well as the number of hospitalizations (see Figure 3). In order to do so, we used data provided by Sciensano, the Belgian institute for health responsible for the epidemiological follow-up of the COVID-19 epidemic [55]. Their daily updates on both crucial parameters explain why certain measures were taken to flatten the curves. More specifically, Figures 2 and 3 reveal that the strict economic and social lockdowns, in the period of 18 March to 18 May 2020 as well as in the period from 19 October 2020 up until the first period of 2021, were driven by the increasing pace at which daily numbers were rising. 


\section{Daily new cases Flanders}

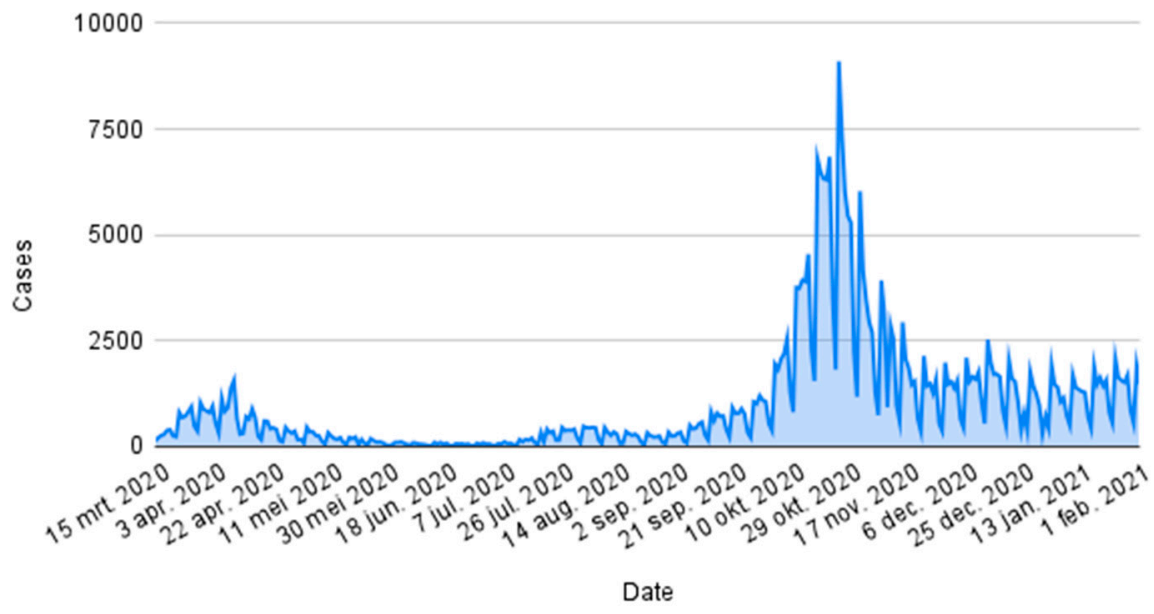

Figure 2. Daily number of new COVID-19 cases in Flanders from 15 March 2020 to 2 February $2021[56]$.

\section{Daily hospitalisations Flanders}

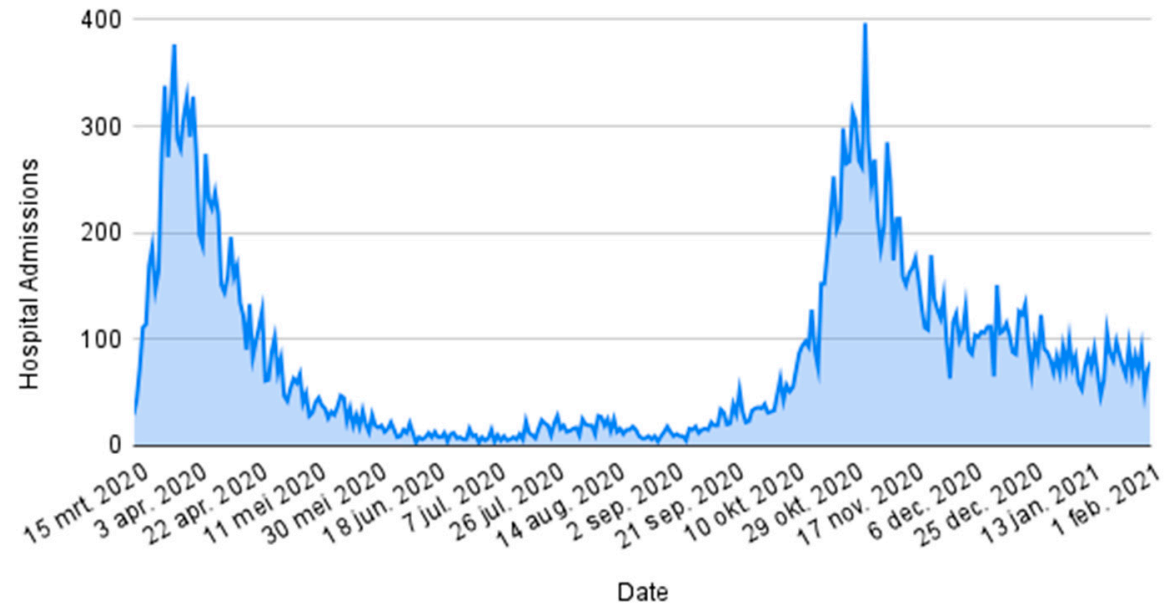

Figure 3. Daily number of new COVID-related hospitalizations in Flanders from 15 March 2020 to 2 February 2021 [56].

\subsubsection{Economic Situation}

The two abovementioned public health parameters are considered to be the main drivers of the economic lockdowns which occurred during the period of 18 March to 18 May 2020 as well as in the period from 19 October 2020 up until the first period of 2021. These economic lockdowns highly affected the Belgian SME population, to which our subset of Flemish growth-oriented firms belongs. In this study, we adhere to the European definition of SMEs which are defined by the European Commission [57] as having less than 250 persons employed, an annual turnover of up to 50 million euros, or a balance sheet total of no more than 43 million euros. In general, SMEs form $99.8 \%$ of the Belgian enterprise population, with a total number of 646,886 SMEs in 2020 of which on average $60 \%$ is active in the Flemish part of Belgium [58]. Economically, these SMEs highly contribute to the economic welfare as they generate about $61 \%$ of total value added and $65 \%$ of employment in the non-financial business economy. The added value per person employed in 2020 was $€ 75,100$, which is almost $10 \%$ lower than in 2019 [58]. This productivity decrease is due to the general decrease in demand caused by the lockdowns as the consumption rate of Belgian households decreased with almost $9 \%$ in 2020 [59]. Overall, the Belgian gross 
domestic product (GDP) decreased with 6.3\% in 2020, the biggest decline since World War II [59].

All these figures highlight the economic impact of the COVID-19 crisis within the SME landscape. In order to tackle lower added value, liquidity issues, and other risks like lower employment rates, the Flemish government has put in place several support measures for SMEs like tax-free compensation premiums, lump sum allowances, extension of deadlines to comply with tax obligations (e.g., real estate tax), and more attractive conditions and tax incentives for loans and share participations. On top of the Flemish support measures, federal supporting mechanisms like credit payment deferrals, a guaranteed credit program, and a moratorium on bankruptcies were put in place [60].

In the following section, we will describe the sample used in this study. As will be made clear, the timing of our data collection is directly related to the most impactful moments for the Belgian economy as it overlaps with the most severe lockdown periods as mentioned above.

\subsection{Sample and Methods}

Our sample consists of Belgian owner-managers of Flemish-based growing SMEs. All entrepreneurs belong to the Impulse Centre for Growth Management (IGMO) of the Vlerick Business School. IGMO is a platform for research, open dialogue, and networking of growth-oriented firms. On average, the IGMO community consists of about 180 active member-entrepreneurs. Membership selection is based on an intake interview with potential candidates in which a track record of fast growth in previous years as well as high growth ambitions for the future are detected. No hard cut-off percentages are used within this growth pattern but a clear explicit growth ambition needs to be detectable. Other selection criteria for IGMO membership are minimum 50 full-time employees and the fact that the growth-oriented firm is directed by an owner-manager. IGMO members represent a broad range of industries (e.g., IT, manufacturing, services, retail, construction) such that it can be considered as a general representation of Flemish growth-oriented firms.

To answer research questions 1 and 2, a survey was sent to all 180 active members of the IGMO community. The main purpose of this specific data collection period was related to gaining insights into the measures taken by our respondents related to the first economic lockdown in Belgium. In a time period of six consecutive weeks, the survey was sent out each week to all 180 IGMO members. A total of 259 responses were collected through these weekly-based short surveys in the period between 18 March and 5 May 2020 (Weekly response rate: $\mathrm{N}=43$ in week $1, \mathrm{~N}=48$ in week $2, \mathrm{~N}=41$ in week $3, \mathrm{~N}=46$ in week 4 , $\mathrm{N}=42$ in week 5 and $\mathrm{N}=39$ in week 6). This implies that on average 44 growth-oriented entrepreneurs participated, which is a response rate of about $24 \%$. Our time period can directly be related to the first Belgian lockdown period as described in Figures 2 and 3.

To answer research question 3, an additional survey was sent out in December 2020 to the same group of 180 active IGMO members, without weekly repeating the data collection procedure as was the case in the first data collection round. The main purpose of this specific data collection period was related to gaining insights in the viewpoints of our respondents regarding the major changes that will be transferred to 2021 in comparison to the pre-COVID period as well as the challenges ahead in 2021. With this second survey we were also able to identify differences in perceived challenges and respective reactions compared to the data collection in the first wave. A total of 84 responses were collected in December 2020, implying a response rate of about $47 \%$. This period can be directly related to the second Belgian lockdown period as described in Figures 2 and 3.

Both surveys included closed- and open-ended questions. This not only allowed us to identify trends but also to get authentic feedback and give entrepreneurs the opportunity to voice their opinion and experience in their own words.

For this explorative study, the most important closed-ended question of survey 1 was 'on which business function does the COVID-19 crisis currently has the most impact?' Respondents were given six possibilities (HR, finance, operations, supply chain, sales, and other business 
functions). We used descriptive statistical methods in order to gain insights into the responses to this closed-end survey item (for findings, see Section 4.1.1). Concerning the most relevant open-ended questions of survey 1 , respondents were asked, 'which actions did you take to respond to the COVID-19 impact?' and 'what lessons did you learn from this crisis period?' We applied inductive coding methods in order to cluster the responses to these open-ended questions into relevant response categories (for findings, see Section 4.1.2).

In survey 2, the same closed-end survey item, 'on which business function does the COVID-19 crisis currently has the most impact?' with the same answering possibilities was incorporated. In contrast to survey 1 , we transformed the question about actions taken from open-ended to closed-ended, given that more insights on general actions due to COVID-19 in comparison to the first period were gained. Specifically, the following closedend question was used: what actions did you take to control damage? Respondents were given seven possibilities (making the existing product and service offering as coronaproof as possible, changing pricing policy, entering different markets or market segments, introducing new products and/or services, strengthening the existing client relationships, making the offering more digital, and other actions). We again used descriptive statistical methods in order to gain insights into the responses to the closed-end survey items (for findings, see Sections 4.2.1 and 4.2.2). With regard to the open-ended questions in survey 2, we asked respondents a question in which they were asked to reflect on the impact of COVID-19 on their business in 2020 by using the survey item 'what lessons did you learn in 2020 from the COVID-19 crisis period?' Additionally, we also asked them to look forward by asking 'what is your main remaining challenge for 2021?' We again applied inductive coding methods in order to cluster the responses to these open-ended questions into relevant response categories (for findings, see Sections 4.2.2 and 4.3).

\section{Findings}

\subsection{Entrepreneurs during the First Wave}

4.1.1. What Are the Specific Challenges That Growth-Oriented Firms Are Facing?

As shown in Figure 4, during the first wave, the most heavily impacted business functions were operations $(23 \%)$ and sales $(60 \%)$, with a shift that took place from operations as most heavily impacted function to sales as the crisis continued. Firms tried to continue selling their inventory in the first weeks of the crisis; however, they had to restrain their efforts as many clients stopped buying.

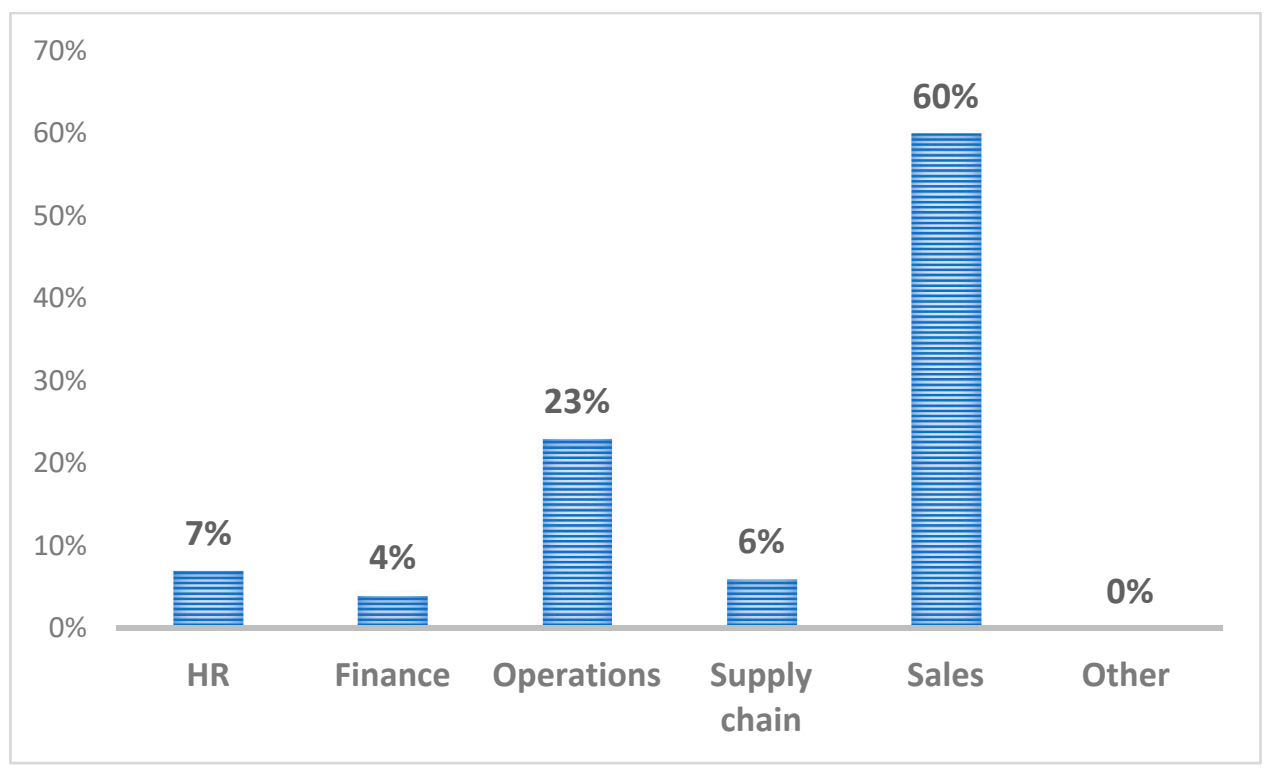

Figure 4. Most heavily impacted business functions during first wave (average percentage over the 6-weekly data points between 18 March and 5 May). 


\subsubsection{How Did Entrepreneurs of Growth-Oriented Firms React to These Challenges?}

As a reaction to the abovementioned challenges, the growth-oriented entrepreneurs have taken actions that contribute to the development of entrepreneurial resilience capabilities [43]. We asked all respondents which specific actions they took, and classified them into actions that contribute to the creation of either operating or dynamic capabilities $[43,47]$. After applying an inductive coding methodology, we identified different categories of reactions that emerged out of our data. Reactions to the COVID-19 crisis that are mostly routine-based were labelled as actions contributing to the firm's operating capabilities as they assist the firm in executing its key operating activities during the COVID-19 (i.e., management of cash positions, frequent and transparent communication, taking care of workforce). Reactions that require significant change and reconfiguration in the firm's strategy, routines, or managerial skills were labelled as actions that contribute to the firm's dynamic capabilities (i.e., creation of new revenue models, build-measure-learn from customer viewpoint, switching roles of the growth-oriented entrepreneurs, build-measurelearn from viewpoint of peer-related networks) in line with contemporary definitions, e.g., $[49,51,52]$ of operating and dynamic capabilities.

4.1.2.1. Actions Taken by Entrepreneurs That Contribute to the Creation of Operating and Dynamic Capabilities

The responses of the weekly surveys sent out during the first wave were summarized, and they showed that the following actions related to the creation of operating capabilities were most often taken by the growth-oriented entrepreneurs:

(1) Management of cash positions: When the crisis emerged, the first action performed by the CEOs was to manage their cash positions. This was frequently done through the means of utilizing credit lines, by using the support measures provided by the government, using the temporary unemployment system, and by ensuring unpaid invoices were settled as soon as possible.

(2) Frequent and transparent communication: Communication from the $\mathrm{CEO}$ (and top management) to all employees was a crucial action to keep the workforce informed; connected to the firm; and, most importantly, motivated. The communication was however not 'good news only' but included decisions on cost cutting initiatives such as temporary unemployment. The majority of the entrepreneurs indicated that they communicated to all their employees once a week, whereas several of them had multiple weekly updates. The communication was often not only a top-down communication, but also involved the feedback from the employees.

(3) Taking care of workforce: When employees are working in difficult circumstances, such as when they are working from home or when they are on temporary unemployment, the relationship between employer and employee is likely to be strained. To keep the connection and motivation, entrepreneurs not only communicated frequently with their employees, but they showed their appreciation through (light) rewarding initiatives or by taking extra health measures.

The responses of the weekly surveys sent out during the first wave were summarized and showed that the following actions related to the creation of dynamic capabilities were most often taken by the growth-oriented entrepreneurs:

(1) Creation of new revenue models: Cash management is not merely looking into cost cutting. It also includes increasing incoming cash. In a difficult period for the core business and their main customers, entrepreneurs started looking for new customer segments, sales channels, and innovative business models that leveraged from their traditional revenue models.

(2) Build-measure-learn from customer viewpoint: In a time when they tended to lose connection with their clients, entrepreneurs proactively reached out to them to ask if they could help them with a different offering (B2C), to give them advice on cash management (B2B) or just to give them information on their specific situation (B2B). 
This was achieved by frequent contact with their clients, with several entrepreneurs calling 15-20 clients per day.

(3) Switching roles of the growth-oriented entrepreneurs: When a firm grows, the entrepreneurs frequently take a step back from the day-to-day operational management tasks as he or she moves on to take on a more strategic role. When the crisis emerged, the entrepreneurs took a step forward by taking control of the operational management functions to be on top of things within the firm. This allowed for faster decision-making as they felt they had sufficient knowledge about all aspects of the business. This way, the role division within the firm was changed to be able to dynamically react to the crisis.

(4) Build-measure-learn from viewpoint of peer-related networks: In times of crisis, entrepreneurs can face situations and problems that are unprecedented. If they can rely on the proximity of a group of entrepreneurs that are facing the same problems, a situation unfolds where entrepreneurs ask for advice and share best practices. Moreover, hearing stories of other entrepreneurs make one realize that 'they are all in this together' and can give them the motivation to carry on. These networks exist through employer's organizations or through business schools.

4.1.2.2. Lessons Learned by Entrepreneurs during First Wave That Contribute to Building Entrepreneurial Resilience

After analyzing and summarizing the responses through which actions were taken that could contribute to the development of both operating and dynamic capabilities, we also looked into the lessons learned from the first wave. These lessons learned can be considered as contributions to the development process in which Flemish growthoriented entrepreneurs built entrepreneurial resilience as a response to the first wave of the COVID-19 crisis. The responses of the weekly surveys sent out during the first wave were summarized and showed that the following elements can be considered as supporting factors in the creation of entrepreneurial resilience of our respondents:

(1) New growth-related approaches: In the years before COVID-19 hit, many firms realized decent growth rates. These growth rates resulted in the development of larger firms as well as more complex firms which are harder to manage. The crisis highlighted the need for sustainable and qualitative growth. The crisis called for responsible leaders who act to generate long term welfare for both the firm and society.

(2) Digital approaches: The COVID-19 crisis has sped up the digitalization process in several ways. Entrepreneurs now felt the urge to sell via online channels, as it was frequently one of the only channels left to sell to their clients (especially for B2C firms). Additionally, the forced teleworking led to a surge in the use of videoconferencing software. Entrepreneurs who were reluctant to allow their employees to telework-let alone to telework themselves-have clearly seen the added value as videoconferencing allowed them to communicate in an efficient way, not only with co-workers, but also with clients and suppliers. This may result in less physical meetings in post-corona times.

(3) Innovative business model approaches: Entrepreneurs were forced to come up with new creative sales approaches and adaptations to their business model. They reported that the urgency of making fast decisions led to surprisingly good results, whereas, in a non-crisis period, the launch of new concepts was done in a more bureaucratic manner as they strived to reach perfection.

(4) Crisis planning: A small minority of firms in our sample had a contingency plan before the COVID-19 crisis hit. These plans help an organization to respond effectively to a future crisis situation, as it can provide clear guidelines on how and when to take certain actions (e.g., what will be the first action to cut in the cost structure, what will we do to find additional revenue). Once the crisis emerged, firms created 'ad hoc' plans which may have resulted in suboptimal decisions. The absence of a clear crisis plan that was made during normal times was clearly a disadvantage 
for many entrepreneurs. They realized that they need a contingency plan for future negative events.

(5) Innovative supply chain approaches: Entrepreneurs faced difficult situations in which they could not produce goods or deliver services any longer as soon as one supplier of a key component was no longer able to deliver. These severe supply chain hiccups made entrepreneurs realize that they were too dependent on one supplier. Having a parallel supply chain for critical components may prevent firms from seizing their operation if one firm cannot deliver on time.

(6) Innovative business process approaches: In crisis times, several business processes must withstand turbulent circumstances. This can highlight weaknesses. By taking on a more operational role during the crisis, entrepreneurs realized that some existing processes were not as efficient as they initially thought. They came to realize for example that automatization of multiple internal processes was crucial. At the same time, it became clear where the firm had slack resources and where the firm lacked certain skills.

(7) Crisis management function: There is an everlasting tension between entrepreneurship and management. Good entrepreneurs are often not good managers and vice versa. Entrepreneurs are creative and like exploring new things. Managers tend to plan, control, and exploit the existing business. Entrepreneurs who had taken a step back from their managerial tasks to focus on their strengths (such as business model innovation or strategic development) reported that they took on the role of crisis manager as they felt that they could add value in this role. The uncertainty that needs to be managed, the creative skills that are needed to come up with new processes, and the quick decision-making that is inherent to a crisis are all tasks which appeared to be closely related to the entrepreneurial DNA.

\subsection{Entrepreneurs during the Second Wave}

4.2.1. What Are the Specific Challenges That Growth-Oriented Firms Are Facing?

As shown in Figure 5, also in the second wave, the sales function was reported to be most impacted $(45 \%)$, again followed by operations $(27 \%)$. However, during the first wave the sales function was more frequently mentioned to have the highest impact (60\%), whereas operations was mentioned by $23 \%$ of the entrepreneurs at that time. Hence, the most heavily impacted functions during the second wave remain the same, but it appears that the difference between sales and operations became smaller. A reason for this can be found in the fact that the sales team had already become more acquainted with selling in a digital way, and clients had become more comfortable with making buying decisions digitally.

\subsubsection{How Did Entrepreneurs of Growth-Oriented Firms React to These Challenges?}

Again, as a response to the challenges endured in the second wave, the growthoriented entrepreneurs took actions that contributed to the development of entrepreneurial resilience capabilities [43]. We again asked all respondents which specific actions they took. In line with Section 4.1.2 we again labelled reactions that are mostly routine-based as actions contributing to the firm's operating capabilities as they assist the firm in executing its key operating activities during the COVID-19 (i.e., making the current offering COVIDproof by, for example, using antibacterial hand gel or face masks). Reactions that require significant change and reconfiguration in the firm's strategy, routines, or managerial skills were labelled as actions that contribute to the firm's dynamic capabilities (e.g., renewed customer relationships, new ways of doing business). It became clear that more actions related to the development of dynamic instead of operating capabilities were taken. 


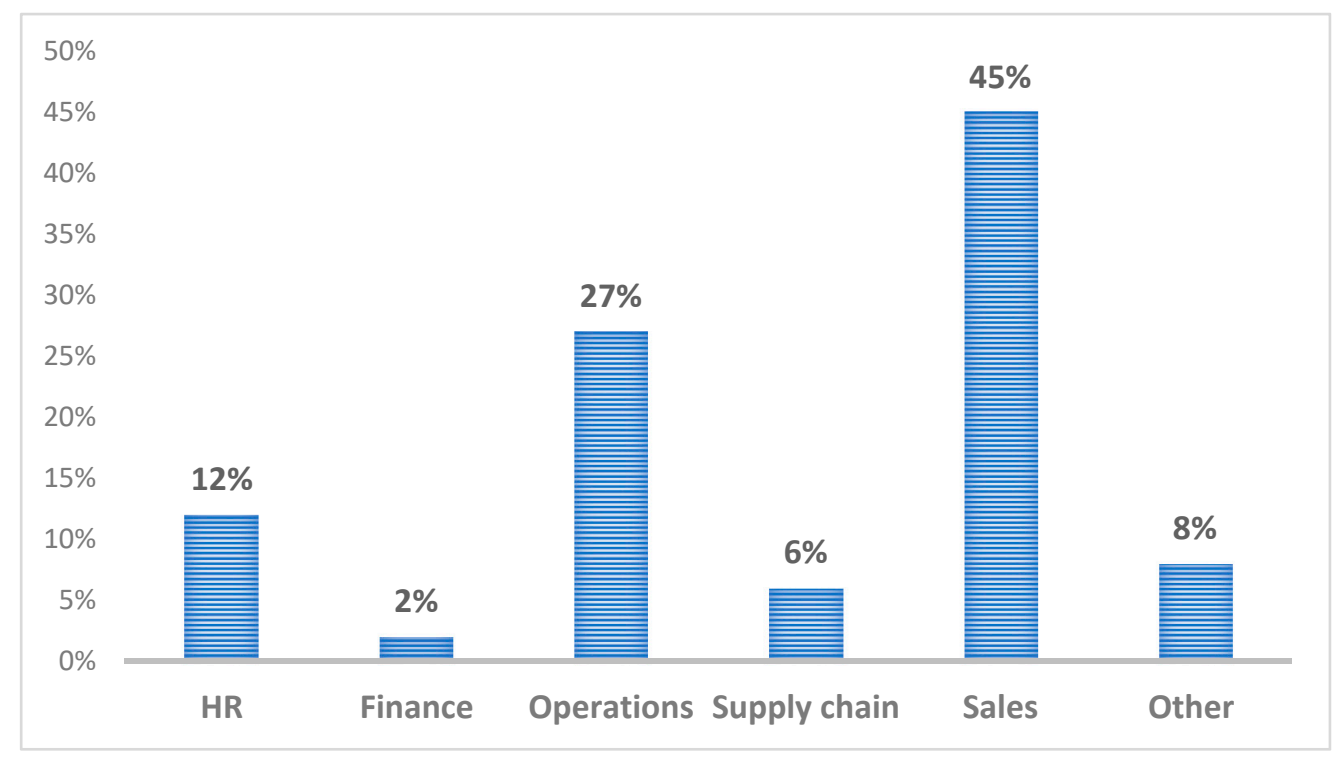

Figure 5. Most heavily impacted business functions during second wave.

4.2.2.1. Actions Taken by Entrepreneurs That Contribute to Creation of Operating and Dynamic Capabilities

When the second COVID-19 wave hit Belgium in the fall of 2020, many growthoriented entrepreneurs already developed several operating and dynamic capabilities (see Section 4.1.2). An overview of the most important actions taken in the second wave are summarized in Figure 6 below.

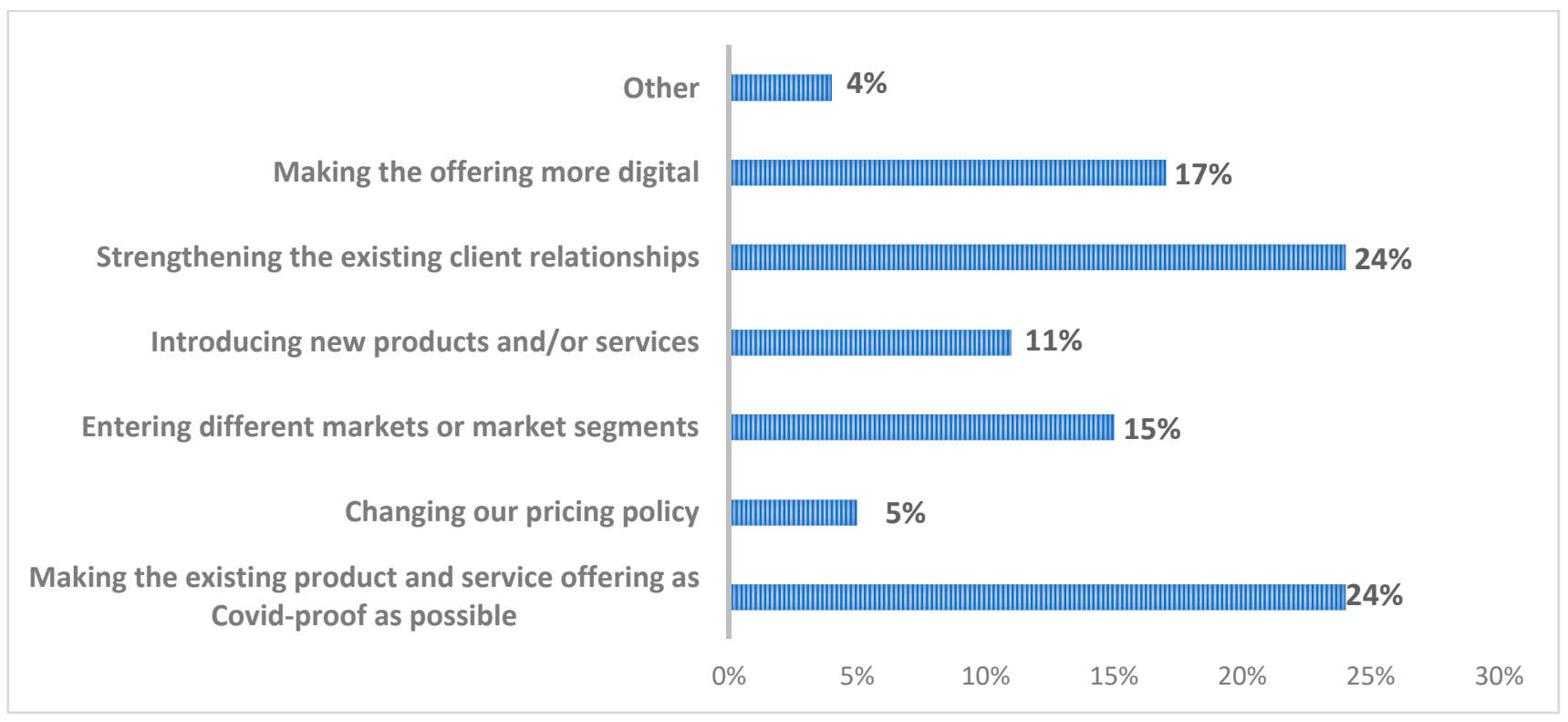

Figure 6. Primary actions taken to control damage at the beginning of the second wave.

The following actions related to the creation of operating capabilities were most often taken by the growth-oriented entrepreneurs during the second wave:

(1) COVID-proof offering: $24 \%$ of the entrepreneurs indicated that making their offering as COVID-proof as possible was their primary focus.

The following actions related to the creation of dynamic capabilities were most often taken by the growth-oriented entrepreneurs during the second wave: 
(1) Renewed customer relationships: $24 \%$ of the entrepreneurs mentioned that they focused on strengthening the relationships with the existing clients while also looking at new ways to manage these relationships.

(2) New ways of doing business: Multiple actions were taken to further enhance the reframing of the ways in which the growth-oriented firms do business. This was achieved by, for example, making their offering more digital $(17 \%)$, entering new market segments $(15 \%)$, introducing new products or services $(11 \%)$, looking at new pricing policies $(5 \%)$, and "other actions" $(4 \%)$ such as strengthening their sales department by retraining certain employees to a sales role.

\subsubsection{Lessons Learned by Entrepreneurs}

The responses of the year-end survey of 2020, sent out during the second wave, were summarized, and showed that the following three elements can be considered as supporting factors in the creation of entrepreneurial resilience of our respondents, in addition to the ones already created during the first wave (see Section 4.1.2.2):

(1) New ways of working: Almost $50 \%$ of the entrepreneurs indicated that more telework, less business traveling, and more flexibility in managing the workplace created more resilience in crisis periods. In particular, the more severe measures during the second wave made such aspects crucial for making sure that all employees could perform their function within the firm without losing productivity.

(2) Optimal use of digital approaches: The digitalization developments already enhanced the entrepreneurs' resilience during the first wave. In the second wave, they could even more easily switch back to telework and online meetings such that work productivity was not hampered. Additionally, the already digitalized firm processes and tools were further optimized such that the impact on the way of working and communicating was less severe.

(3) Newly created sales approaches: Given the changes made in the business models of their firms, the entrepreneurs put even more emphasis on different and enhanced relationships with customers and suppliers such that no sales delay could impact firm performance. They also looked at more profitable product mixes, with new products and services offered more quickly to the customers.

\subsection{Remaining Challenges in 2021 According to the Resilient Growth Firms}

Finally, in our second survey in December 2020, we asked the growth-related entrepreneurs to take a look forward towards 2021. Even though they tackled many unforeseen challenges, we wanted to know which challenges for 2021 they think they would face despite the fact that they had become more resilient. We summarized the major challenges of 2021 by categorizing the answers to this open question as follows:

(1) Keeping revenues on point and creating sales growth opportunities

(2) Continuation of firm growth, both nationally and internationally

(3) Maintaining human and financial resources

(4) Rebuilding firm culture and trust with stakeholders

(5) Staying agile towards new crises

\section{Results and Discussion}

COVID-19 has changed the rules of the game in our society. The pandemic is a public health crisis with profound implications for all entrepreneurs and their ventures. As the ground rules shifted like never before, many firms struggled to survive while others even were forced into liquidation. As with all crises, the good news is that challenges often entail learning opportunities. Winston Churchill once famously said, "never let a good crisis go to waste" [61], meaning that learning opportunities might also exist in the ongoing COVID-19 crisis. Prior research has shown that economic crises can help entrepreneurs to build entrepreneurial resilience [10,62]. For this reason, the objective of this study was to investigate how the COVID-19 crisis has forced growth-oriented firms to build 
entrepreneurial resilience. The focus of this study is on growth-oriented firms for two reasons. First, while the economic importance of growth-oriented firms in terms of wealthand net job creation is self-evident, research on how the COVID-19 crisis is impacting these firms is scarce. Second, the way in which an external threat like COVID-19 is impacting organizations seems to be highly firm-specific [43]. For example, in general terms and faced with the same COVID-19 pandemic, a small or micro firm may face different threats as opposed to a growth-oriented firm.

As prior literature has shown, building entrepreneurial resilience follows a process that needs to be developed in relation to specific threats [43]. Indeed, threats can differ in their make-up and this make-up is crucial in order to fully grasp how to guard against these threats and build entrepreneurial resilience. Additionally, the way in which these threats are perceived and/or experienced also depends on the type of firm that is confronted with these threats. Therefore, to understand the process of building entrepreneurial resilience, it is important to have a clear understanding of how growth-oriented firms have perceived these specific COVID-19 related threats. Accordingly, the first research questions (RQ1) of this explorative study deals with identifying the specific challenges growth-oriented firms are facing as a result of the COVID-19 crisis. The results of our study show that growth-oriented firms are facing a wide variety of threats ranging from HR to finance, operations, supply chain, and sales. Our data show that threats related to operations and sales were the ones having the biggest impact on the firm. When we look at the different time frames in which this study took place, we see that operations-related threats were especially perceived as very important in the beginning of the COVID-19 crisis (i.e., end of March/early April 2020) but the perceived importance of these operation-related threats decreased as the crisis continued. Conversely, our results show an opposite trend for sales-related challenges. Namely, although sales was already identified as a challenge in the beginning of the COVID-19 crisis, our results show that sales-related challenges became even more important as the crisis continued, reaching a peak at the end of wave 1 (i.e., week 27 April-1 May). In wave 2 of the COVID-19 pandemic, the most heavily impacted functions remained the same, but it appears that the difference between sales-related and operations-related threats became smaller.

To further unravel the process of building entrepreneurial resilience, we must look beyond the perceived challenges that growth-oriented firms are facing. As suggested by the theoretical framework of Manfield and Newey [43], firms need to respond to a specific organizational threat in order to deliberately learn, build capabilities, and ultimately become more resilient. In other words, mapping the threat response landscape by categorizing the different actions growth-oriented firms have taken can help us to reveal how resilience is built during the COVID-19 crisis. Therefore, our second research question (RQ2) was devoted to revealing the firms' responses and was formulated as follows: How did entrepreneurs of growth-oriented firms react to these challenges? Here, our data reveal a similar trend as in RQ1. Namely, when the COVID-19 crisis first kicked in, the initial reactions were very operational and mostly related to short-term survival. Examples of these operational responses were management of cash positions, frequent and transparent communication with employees, and taking care of the workforce. Based on these findings we can conclude that especially in the beginning of the COVID-19 crisis, growth-oriented firms took actions that have helped them to strengthen their operating capabilities as these capabilities are usually routine-based and support a firm in executing its key operating activities $[48,49]$. Next to the important actions that relate to building operating capabilities, our data show that growth-oriented entrepreneurs already took a first step in building dynamic capabilities during wave 1 by initiating actions that relate to reconfiguring existing competences. For example, in wave 1 entrepreneurs indicated that they already started looking for new customer segments, applied a build-measure-learn approach [63] in interacting with customers and peers, and reconfigured their role by integrating their strategic thinking abilities with day-to-day operational management when necessary. All these actions can be seen as examples of how growth-oriented entrepreneurs already started 
building dynamic capabilities in wave 1 of the COVID-19 crisis. The focus on actions that relate to building dynamic capabilities became even more profound during the second wave. As the crisis endured our data show a shift in the type of actions growth-oriented entrepreneurs were taking. The results of our empirical study indicate that growth-oriented firms shifted their focus from responses that relate to short-term survival to responses that related more to long-term growth and opportunity identification. Examples of such actions that have helped these firms to further build their dynamic capabilities are renewed customer relationships, exploring new ways of doing business, and the creation of sustainable partnerships. Building such dynamic capabilities is a fundamental prerequisite in order to survive the COVID-19 crisis. It seems especially relevant for growth-oriented firms as they need to adapt and change if they want to reach a new homeostasis, i.e., 'bouncing forward' [43], meaning they not only want to recover from the ongoing COVID-19 crisis but also attempt to achieve their growth ambitions. Future research might investigate to what extend our findings also hold for firms that did not have such an explicit growth ambition. It might be interesting for future researchers to investigate to what extent a firm's growth ambition prior to the COVID-19 crisis has helped them to build new capabilities and ultimately survive the COVID-19 crisis.

Our final research question related to the lessons learned and how entrepreneurs of growth-oriented firms perceive the future (RQ 3). In this context, prior research has shown that entrepreneurship is highly dependent on the current economic climate and is expected to be highly influenced by crises [4]. For this reason, we expected to find a rather negative outlook as the COVID-19 crisis has significantly impacted entrepreneurs. Surprisingly, our data show that growth-oriented entrepreneurs are still quite positive about the future. We identified a plethora of lessons that entrepreneurs learned during the crisis. Examples of entrepreneurial learning [64] during the COVID-19 crisis which we identified in our data range from innovation in supply chain-business processes and business models - to digitalization, and crisis management. In line with Greiner's [65] evolutionary view on firm growth, entrepreneurs should fully exploit past events and experiences in order to both gain a clearer comprehension of the current crisis as well as being better prepared for future crises and move successfully from one growth stage to another. We find support for this premise as most growth-oriented entrepreneurs indicate that firm growth, both nationally and internationally, is still high on their agenda. We can conclude that the growth-oriented firms in our sample still see growth opportunities in the future. There are, however, some important challenges which they believe are crucial in order to succeed in their growth ambitions. Examples of such growth-related challenges are maintaining human and financial resources and rebuilding firm culture and trust with important stakeholders.

The findings of this study provide interesting insights for future research. First, to the best of our knowledge, our study is the first to investigate the complex "challenge-reactionlearning loop" for growth-oriented firms during the COVID-19 pandemic in Flanders. In this specific context, our results revealed the most prominent challenges, reactions, and lessons learned in a crisis like the COVID-19 pandemic. For this reason, our findings provide a fertile ground for future researchers to investigate to what extent current findings also hold for other type of firms (e.g., micro-firms, family firms, publicly quoted firms) or in other geographical contexts. For example, our results revealed that threats related to operations and sales where the ones having the biggest impact on growth-oriented firms. Future studies could assess if this observation is common for all type of firms or to what extent firm-specific goals may alter the importance of perceived challenges induced by an external crisis like the COVID-19 pandemic. For example, family firms are often characterized by the importance they attach to non-financial family-related goals such as the perpetuation of the family dynasty, binding social ties, and emotional attachment, e.g., [66-69]. It would be interesting to scrutinize the impact of such non-financial familyrelated goals on the perceived challenges induced by the COVID-19 pandemic. Family firms may have experienced the impact of the COVID-19 crisis differently as a result of 
their non-financial goals in such a way that other business functions, like HR, might have had a bigger impact. Additionally, another interesting area for future research relates to the temporal aspect of the perceived challenges during the crisis. In the context of Flemish growth-oriented firms, our data show that sales related challenges reached their peak at the end of wave 1 (i.e., week 27 April-1 May) and slightly decreased afterwards. This temporal element might be an interesting future research topic to investigate how the importance of sales-related challenges evolves over time in other type of firms during an economic crisis. Indeed, in business plans for start-ups and scale-ups, sales is usually seen as the first item forecast because it captures volume of business [70]. For this reason, these types of firms are often highly concerned with their sales numbers. Nevertheless, from a capital markets perspective, it could be argued that "bigger isn't always better". Increased volume of business will only translate into added value for shareholders if this expansion is accompanied by cost control [71,72]. Depending on the type of firm and respective strategic goals, this "bigger isn't always better" idea might explain why some firms might perceive other business functions as more important over time vis-à-vis the growth-oriented firms in scope of our study. For example, family firms that place high importance on the preservation of their non-financial family goals might have had other priorities apart from their sales function in the very beginning of the COVID-19 crisis. Indeed, family firms are said to be loss averse when it comes to threats to their non-financial family goals (e.g., relinquishing family control, creating or saving jobs for family members) even if this means accepting a greater performance hazard [68,73]. For this reason, it might be an interesting future research area to investigate the perceived (temporal) importance of the sales function in family firms during an economic crisis compared to the growthoriented firms in this study. An interesting research question in this context might be the following: are family firms willing to first incur a greater decrease in sales at the beginning of a crisis and focus on cost-cutting, if this is what it takes to protect their non-financial family goals? Consequently, does the perceived importance of the sales function increase during the crisis once these non-financial family goals are secured? In this line, a number of possible future research questions related to the perceived (temporal) importance of business challenges induced by an economic crisis exist. We especially encourage future researchers to investigate how and to what extent firm goals prior to the economic crisis might affect these perceived challenges. Recently, Kuckertz and Brändle [21] also suggested that the way in which entrepreneurial resilience is built may depend on a firm's specific position prior to the crisis and the scope of the impact on the resources available to them during the crisis. A limitation of our study is that we did not control for the participating respondents' (financial) resources available prior to the crisis which leaves an interesting research opportunity for future endeavors.

In line with the previous future research questions, it might also be interesting to explicitly investigate to what extent the entrepreneurial resilience as a result of the "challengereaction-learning loop" during an economic crisis has an effect on business continuity and sustainability practices [74] after the crisis. Large scale longitudinal research designs may help future researchers to scrutinize how the behavior of firms has changed after the crisis as a result of the acquired entrepreneurial resilience and consequently evaluate the long-term effects of the different actions taken by the entrepreneurs in terms of revenues, clients' portfolio, changes in supply and demand structure, profitability, employment, sustainability practices, etc. Furthermore, this explorative study did not investigate the effect of entrepreneurial resilience on latent entrepreneurship variables that have an undisputed effect on firm performance. Future research might therefore rely on quantitative research designs to investigate how the COVID-19 crisis and respective entrepreneurial resilience has had an effect on conventional latent entrepreneurship variables like entrepreneurial orientation (EO), e.g., [75,76]; strategic entrepreneurial behavior (SEB) [77]; or entrepreneurial passion (EP), e.g., [78-80]. From a methodological point of view, qualitative research designs or even mixed-method research designs [81] combining surveys, content 
analysis, and in-depth expert interviews might deepen our understanding of the proposed "challenge-reaction-learning loop".

The findings of this study have a number of important implications for future practice and policy. First, there are a number of practical implications for growth-oriented entrepreneurs and their advisors. The findings in our study may guide these entrepreneurs in their own journey to build entrepreneurial resilience as we have revealed how other growth-oriented entrepreneurs have dealt with the COVID-19 crisis. Sharing knowledge with significant others has proven to have a positive effect on the net asset and added value growth of these firms $[82,83]$. Therefore, sharing the findings of our study with growth-oriented entrepreneurs and their advisors might help them to improve their own "challenge-reaction-learning loop" as this study shows how significant others have experienced and dealt with the current COVID-19 pandemic. Moreover, the reported findings on 'lessons learned' are very interesting for other growth-oriented entrepreneurs facing the COVID-19 pandemic. Second, our study also has important implications for policy makers. Prior research has shown that policy makers play an important role in helping firms to recover from the COVID-19 crisis. Although there have been several fiscal and monetary policies adopted by different countries worldwide [84], specific policies aimed at growth-oriented firms are scarce as most government interventions especially aim to support SMEs in general [11]. Our study underscores the importance of growth-oriented firms in terms of their contribution to economic growth and added value, e.g., [16-18]. Therefore, and especially in times of an economic crisis, the recovery of our economy is highly dependent on the resilience of growth-oriented entrepreneurs. Unfortunately, a recent report of the European Commission [11] has exposed the shortcomings of current government support (e.g., the well-known loan schemes and furlough schemes) for growthoriented firms as they appear to be not tailored for the specific needs of this important group of growth-oriented firms. For example, the European Commission claims [11] that government interventions to support the survival and emergence of growth-oriented firms in the recovery phase of the COVID-19 crisis need to be based around alternative forms of financial support (e.g., by specifically increasing the availability of risk capital). The findings of this explorative study may help policy makers to create better tailor-made government support and assist them to introduce alternative forms of (financial) support that build on the specific growth-oriented challenges identified in this research report.

\section{Conclusions}

In sum, we can conclude that building entrepreneurial resilience during the COVID-19 crisis has been an iterative process where the "challenge-reaction-learning loop" has helped growth-oriented firms to build and strengthen their operating and dynamic capabilities needed to survive this global pandemic. Entrepreneurial learning is a continuous process which every firm goes through and often happens unconsciously. Therefore, the articulation of this learning process may be difficult for most entrepreneurs as they are not familiar with reflecting explicitly on such issues [85]. By making this learning process explicit and dividing it into a "challenge-reaction-learning loop", this explorative study contributes to both theory and practice and provides future researchers with a framework to further elucidate how entrepreneurial resilience is built in times of crises.

Author Contributions: Conceptualization, J.S., P.V. \& Y.D.; methodology, J.S., P.V. \& Y.D.; software, J.S., P.V. \& Y.D.; validation, J.S., P.V. \& Y.D.; formal analysis, J.S., P.V. \& Y.D.; investigation, J.S., P.V. \& Y.D.; resources, J.S., P.V. \& Y.D.; data curation, J.S., P.V. \& Y.D.; writing—original draft preparation, J.S., P.V. \& Y.D.; writing-review and editing, J.S., P.V. \& Y.D.; visualization, J.S., P.V. \& Y.D.; supervision, J.S., P.V. \& Y.D.; project administration, J.S., P.V. \& Y.D. All authors have read and agreed to the published version of the manuscript.

Funding: This research received no external funding.

Institutional Review Board Statement: Ethical review and approval were waived for this study since no (sensitive) personal data and information was processed. 
Informed Consent Statement: Informed consent was obtained from all subjects involved in the study.

Data Availability Statement: Data available upon reasonable request (Y.D.).

Conflicts of Interest: The authors declare no conflict of interest.

\section{References}

1. Magretta, J. Why Business Models Matter; Harvard Business School: Boston, MA, USA, 2002.

2. Zilber, T.B. Stories and the discursive dynamics of institutional entrepreneurship: The case of Israeli high-tech after the bubble. Organ. Stud. 2007, 28, 1035-1054. [CrossRef]

3. Vegetti, F.; Adăscăliței, D. The impact of the economic crisis on latent and early entrepreneurship in Europe. Int. Entrep. Manag. J. 2017, 13, 1289-1314. [CrossRef]

4. Klapper, L.; Love, I. The impact of the financial crisis on new firm registration. Econ. Lett. 2011, 113, 1-4. [CrossRef]

5. Devece, C.; Peris-Ortiz, M.; Rueda-Armengot, C. Entrepreneurship during economic crisis: Success factors and paths to failure. J. Bus. Res. 2016, 69, 5366-5370. [CrossRef]

6. Kostis, P.C. Increased Uncertainty, Credit Supply, and Non-Performing Loans in the Eurozone. JBAFP 2020, 2, 1-31. [CrossRef]

7. Ritchie, B.W. Chaos, crises and disasters: A strategic approach to crisis management in the tourism industry. Tour. Manag. 2004, 25, 669-683. [CrossRef]

8. Tsai, C.-H.; Chen, C.-W. The establishment of a rapid natural disaster risk assessment model for the tourism industry. Tour. Manag. 2011, 32, 158-171. [CrossRef]

9. Ayala, J.-C.; Manzano, G. The resilience of the entrepreneur. Influence on the success of the business. A longitudinal analysis. J. Econ. Psychol. 2014, 42, 126-135. [CrossRef]

10. Bullough, A.; Renko, M. Entrepreneurial resilience during challenging times. Bus. Horiz. 2013, 56, 343-350. [CrossRef]

11. Mason, C. The Coronavirus Economic Crisis: Its Impact on Venture Capital and High Growth Enterprises; Publications Office of the European Union: Luxembourg, 2020.

12. Bartik, A.W.; Bertrand, M.; Cullen, Z.; Glaeser, E.L.; Luca, M.; Stanton, C. The impact of COVID-19 on small business outcomes and expectations. Proc. Natl. Acad. Sci. USA 2020, 117, 17656-17666. [CrossRef]

13. Akpan, I.J.; Udoh, E.A.P.; Adebisi, B. Small business awareness and adoption of state-of-the-art technologies in emerging and developing markets, and lessons from the COVID-19 pandemic. J. Small Bus. Entrep. 2020, 1-18. [CrossRef]

14. Fairlie, R.W. The Impact of COVID-19 on Small Business Owners: Continued Losses and the Partial Rebound in May 2020; National Bureau of Economic Research: Cambridge, MA, USA, 2020.

15. Buffington, C.; Dennis, C.; Dinlersoz, E.; Foster, L.; Klimek, S. Measuring the Effect of COVID-19 on us Small Businesses: The Small Business Pulse Survey; USCB: Suitland, MD, USA, 2020.

16. Daunfeldt, S.-O.; Halvarsson, D. Are high-growth firms one-hit wonders? Evidence from Sweden. Small Bus. Econ. 2015, 44, 361-383. [CrossRef]

17. Mason, C.; Brown, R. Creating good public policy to support high-growth firms. Small Bus. Econ. 2013, 40, 211-225. [CrossRef]

18. Dillen, Y.; Laveren, E.; Martens, R.; De Vocht, S.; Van Imschoot, E. Growth persistence and profile robustness of high-growth firms. Int. J. Entrep. Ventur. 2014, 6, 299-330. [CrossRef]

19. Henrekson, M.; Johansson, D. Competencies and Institutions Fostering High-Growth Firms; Now Publishers Inc.: Delft, The Netherlands, 2008.

20. Shane, S. Why encouraging more people to become entrepreneurs is bad public policy. Small Bus. Econ. 2009, 33, 141-149. [CrossRef]

21. Kuckertz, A.; Brändle, L. Creative reconstruction: A structured literature review of the early empirical research on the COVID-19 crisis and entrepreneurship. Manag. Rev. Q. 2021, 1-27. [CrossRef]

22. Chattopadhyay, P.; Glick, W.H.; Huber, G.P. Organizational actions in response to threats and opportunities. Acad. Manag. J. 2001, 44, 937-955.

23. Storey, D.J. Understanding the Small Business Sector; Routledge: London, UK, 2016.

24. Henrekson, M.; Johansson, D. Gazelles as job creators: A survey and interpretation of the evidence. Small Bus. Econ. 2010, 35, 227-244. [CrossRef]

25. Anyadike-Danes, M.; Bonner, K.; Hart, M.; Mason, C. Measuring Business Growth: High-Growth Firms and Their Contribution to Employment in the UK; National Endowment for Science, Technology and the Arts (NESTA): London, UK, 2009.

26. Hölzl, W. High growth firms in Europe. Science, Research and Innovation performance of the EU; European Commission: Brussels, Belgium, 2016; pp. 247-276.

27. European Commission. Europe 2020: A Strategy for Smart, Sustainable and Inclusive Growth; European Commission: Brussels, Belgium, 2010.

28. OECD. High. Growth Enterprises; OECD: Paris, France, 2010.

29. Caloghirou, Y.; Giotopoulos, I.; Kontolaimou, A.; Tsakanikas, A. Inside the black box of high-growth firms in a crisis-hit economy: Corporate strategy, employee human capital and R\&D capabilities. Int. Entrep. Manag. J. 2020, 1-27. [CrossRef]

30. Chen, R.; Xie, Y.; Liu, Y. Defining, Conceptualizing, and Measuring Organizational Resilience: A Multiple Case Study. Sustainability 2021, 13, 2517. [CrossRef] 
31. Bonanno, G.A. Loss, trauma, and human resilience: Have we underestimated the human capacity to thrive after extremely aversive events? Am. Psychol. 2004, 59, 20. [CrossRef] [PubMed]

32. Adger, W.N. Social and ecological resilience: Are they related? Prog. Hum. Geogr. 2000, 24, 347-364. [CrossRef]

33. Holling, C. Engineering Resilience vs. Ecological Resilience. Engineering within Ecological Constraints; Schulze, P.C., Ed.; National Academy: Washington, DC, USA, 1996.

34. Windle, G. What is resilience? A review and concept analysis. Rev. Clin. Gerontol. 2011, 21, 152. [CrossRef]

35. Brown, J.H.; D’Emidio-Caston, M.; Benard, B. Resilience Education; Corwin Press: Thousand Oaks, CA, USA, 2001.

36. Herrman, H.; Stewart, D.E.; Diaz-Granados, N.; Berger, E.L.; Jackson, B.; Yuen, T. What is resilience? Can. J. Psychiatry 2011, 56, 258-265. [CrossRef]

37. Luthar, S.S.; Cicchetti, D.; Becker, B. The construct of resilience: A critical evaluation and guidelines for future work. Child. Dev. 2000, 71, 543-562. [CrossRef] [PubMed]

38. Ignat, R.; Constantin, M. Multidimensional Facets of Entrepreneurial Resilience during the COVID-19 Crisis through the Lens of the Wealthiest Romanian Counties. Sustainability 2020, 12, 10220. [CrossRef]

39. Tedeschi, R.G.; Calhoun, L.G. Posttraumatic growth: Conceptual foundations and empirical evidence. Psychol. Inq. 2004, 15, 1-18. [CrossRef]

40. Sutcliffe, K.M. Organizing for Resilience. Positive Organizational Scholarship: Foundations of a New Discipline; Cameron, K.S., Dutton, J.E., Quinn, R.E., Eds.; Berrett-Koehler: San Francisco, CA, USA, 2003.

41. Hedner, T.; Abouzeedan, A.; Klofsten, M. Entrepreneurial Resilience; Taylor \& Francis: Abingdon, UK, 2011.

42. Zautra, A.J.; Hall, J.S.; Murray, K.E. Resilience: A new Definition of Health for People and Communities; Guilford Press: New York, NY, USA, 2010.

43. Manfield, R.C.; Newey, L.R. Resilience as an entrepreneurial capability: Integrating insights from a cross-disciplinary comparison. Int. J. Entrep. Behav. Res. 2018, 24, 1155-1180. [CrossRef]

44. Teece, D.J.; Pisano, G.; Shuen, A. Dynamic capabilities and strategic management. Strateg. Manag. J. 1997, 18, 509-533. [CrossRef]

45. Dewald, J.; Bowen, F. Storm clouds and silver linings: Responding to disruptive innovations through cognitive resilience. Entrep. Theory Pract. 2010, 34, 197-218. [CrossRef]

46. Verreynne, M.-L.; Ho, M.; Linnenluecke, M. Editorial for the special issue on: Organizational resilience and the entrepreneurial firm. Int. J. Entrep. Behav. Res. 2018, 24, 1122-1128. [CrossRef]

47. Newey, L.R.; Zahra, S.A. The evolving firm: How dynamic and operating capabilities interact to enable entrepreneurship. Br. J. Manag. 2009, 20, S81-S100. [CrossRef]

48. Zahra, S.A.; Sapienza, H.J.; Davidsson, P. Entrepreneurship and dynamic capabilities: A review, model and research agenda. J. Manag. Stud. 2006, 43, 917-955. [CrossRef]

49. Winter, S.G. Understanding dynamic capabilities. Strateg. Manag. J. 2003, 24, 991-995. [CrossRef]

50. Teece, D.J. Explicating dynamic capabilities: The nature and microfoundations of (sustainable) enterprise performance. Strateg. Manag. J. 2007, 28, 1319-1350. [CrossRef]

51. Cepeda, G.; Vera, D. Dynamic capabilities and operational capabilities: A knowledge management perspective. J. Bus. Res. 2007, 60, 426-437. [CrossRef]

52. Helfat, C.E.; Peteraf, M.A. The dynamic resource-based view: Capability lifecycles. Strateg. Manag. J. 2003, 24, 997-1010. [CrossRef]

53. Eisenhardt, K.M.; Martin, J.A. Dynamic capabilities: What are they? Strateg. Manag. J. 2000, 21, 1105-1121. [CrossRef]

54. Eisenhardt, K.M. Making fast strategic decisions in high-velocity environments. Acad. Manag. J. 1989, 32, $543-576$.

55. Sciensano. The Role Sciensano Plays in the COVID-19 Epidemic. Available online: https://www.sciensano.be/en/health-topics/ coronavirus / role (accessed on 4 February 2021).

56. Sciensano. Belgian Data on COVID-19. Available online: https://www.sciensano.be/en/covid-19-data (accessed on 4 February 2021).

57. European Commission. Commission Recommendation of 6 May 2003 Concerning the Definition of Micro, Small and Medium-Sized Enterprises (Text with Eea Relevance) (Notified under Document Number C(2003) 1422); European Commission: Brussels, Belgium, 2003.

58. European Commission. 2021 SME Country Fact Sheet: Belgium Commission; European Commission: Brussels, Belgium, 2021.

59. SERV. Cijferrapport Corona-Impact op Het Sociaal-Economisch Weefsel; SERV: Camden. NJ, USA, 2020.

60. Deloitte. COVID-19 Subsidies and Grants: Aid Measures Available to Businesses. Available online: https://www2.deloitte.com/ be/en/pages/tax/articles/COVID-19-Subsidies-and-grants-Deloitte-Belgium-Tax.html (accessed on 5 August 2021).

61. Low, A. As Said by Winston Churchill, Never Waste a Good Crisis; Real Business: London, UK, 2016.

62. Maritz, A.; Perenyi, A.; de Waal, G.; Buck, C. Entrepreneurship as the unsung hero during the current COVID-19 economic crisis: Australian perspectives. Sustainability 2020, 12, 4612. [CrossRef]

63. Reis, E. The Lean Startup; Crown Business: New York, NY, USA, 2011.

64. Rae, D. Entrepreneurial learning: A narrative-based conceptual model. J. Small Bus. Enterp. Dev. 2005, 12, 323-335. [CrossRef]

65. Greiner, L.E. Evolution and Revolution as Organizations Grow; Harvard Business Review: Cambridge, MA, USA, 1972.

66. Berrone, P.; Cruz, C.; Gomez-Mejia, L.R. Socioemotional wealth in family firms: Theoretical dimensions, assessment approaches, and agenda for future research. Fam. Bus. Rev. 2012, 25, 258-279. [CrossRef]

67. Gomez-Mejia, L.R.; Campbell, J.T.; Martin, G.; Hoskisson, R.E.; Makri, M.; Sirmon, D.G. Socioemotional wealth as a mixed gamble: Revisiting family firm R\&D investments with the behavioral agency model. Entrep. Theory Pract. 2014, 38, 1351-1374. 
68. Gómez-Mejía, L.R.; Haynes, K.T.; Núñez-Nickel, M.; Jacobson, K.J.L.; Moyano-Fuentes, J. Socioemotional wealth and business risks in family-controlled firms: Evidence from spanish olive oil mills. Adm. Sci. Q. 2007, 52, 106-137. [CrossRef]

69. Schepers, J.; Voordeckers, W.; Steijvers, T.; Laveren, E. Long-Term Orientation as a Resource for Entrepreneurial Orientation in Private Family Firms: The Need for Participative Decision Making. Sustainability 2020, 12, 5334. [CrossRef]

70. Palepu, K.G.; Healy, P.M.; Wright, S.; Bradbury, M.; Coulton, J. Business Analysis and Valuation: Using Financial Statements; Cengage AU: Melbourne, Australia, 2020.

71. De Mello, J. Bigger Isn't Always Better, Case number 2. In Cases in Finance; McGraw-Hill Education: New York, NY, USA, 2006.

72. Tomasko, R.M. Bigger Isn't Always Better; Amacom: New York, NY, USA, 2006.

73. Gómez-Mejía, L.R.; Cruz, C.; Berrone, P.; De Castro, J. The bind that ties: Socioemotional wealth preservation in family firms. Acad. Manag. Ann. 2011, 5, 653-707. [CrossRef]

74. Corrales-Estrada, A.M.; Gómez-Santos, L.L.; Bernal-Torres, C.A.; Rodriguez-López, J.E. Sustainability and Resilience Organizational Capabilities to Enhance Business Continuity Management: A Literature Review. Sustainability 2021, 13, 8196. [CrossRef]

75. Lumpkin, G.T.; Dess, G.G. Clarifying the entrepreneurial orientation construct and linking it to performance. Acad. Manag. Rev. 1996, 21, 135-172. [CrossRef]

76. Covin, J.G.; Lumpkin, G.T. Entrepreneurial orientation theory and research: Reflections on a needed construct. Entrep. Theory Pract. 2011, 35, 855-872. [CrossRef]

77. Anderson, B.S.; Eshima, Y.; Hornsby, J.S. Strategic entrepreneurial behaviors: Construct and scale development. Strateg. Entrep. J. 2019, 13, 199-220. [CrossRef]

78. Cardon, M.S.; Gregoire, D.A.; Stevens, C.E.; Patel, P.C. Measuring entrepreneurial passion: Conceptual foundations and scale validation. J. Bus. Ventur. 2013, 28,373-396. [CrossRef]

79. Cardon, M.S.; Wincent, J.; Singh, J.; Drnovsek, M. The nature and experience of entrepreneurial passion. Acad. Manag. Rev. 2009, 34, 511-532. [CrossRef]

80. De Mol, E.; Cardon, M.S.; de Jong, B.; Khapova, S.N.; Elfring, T. Entrepreneurial passion diversity in new venture teams: An empirical examination of short-and long-term performance implications. J. Bus. Ventur. 2019, 35, 105965. [CrossRef]

81. Choudhary, A.; De, A.; Ahmed, K.; Shankar, R. An integrated fuzzy intuitionistic sustainability assessment framework for manufacturing supply chain: A study of UK based firms. Ann. Oper. Res. 2021, 1-44. [CrossRef]

82. Schoonjans, B.; Van Cauwenberge, P.; Vander Bauwhede, H. Knowledge networking and growth in service firms. Serv. Ind. J. 2013, 33, 1051-1067. [CrossRef]

83. Schoonjans, B.; Van Cauwenberge, P.; Vander Bauwhede, H. Formal business networking and SME growth. Small Bus. Econ. 2013, 41, 169-181. [CrossRef]

84. Lacalle, D.L. Monetary and Fiscal Policies in the COVID-19 Crisis. Will They Work? J. Bus. Account. Financ. Perspect. 2020, 2, 1-28. [CrossRef]

85. Cope, J.; Watts, G. Learning by doing-An exploration of experience, critical incidents and reflection in entrepreneurial learning. Int. J. Entrep. Behav. Res. 2000, 6, 104-124. [CrossRef] 